\title{
The Study of Land Use and Land Cover Pattern Using RS and GIS: A Case Study On Tumakuru Taluk
}

\author{
R. Shivakumar ${ }^{1}$, D. S. Jagadeesha ${ }^{2}$, T. V. Manjuprasad ${ }^{3}$, T. N. Thejesh ${ }^{4 *}$, T. Santhosha ${ }^{5}$, E. Chaithra $^{6}$, \\ T. J. Supriya ${ }^{7}$, Syeda Nikhat Fathima ${ }^{8}$ \\ ${ }^{1}$ Professor \& HoD, Department of Civil Engineering, HMS Institute of Technology, Tumakuru, India \\ ${ }^{2}$ Professor, Department of Civil Engineering, HMS Institute of Technology, Tumakuru, India \\ 3,4,5,6,7,8 Assistant Professor, Department of Civil Engineering, HMS Institute of Technology, Tumakuru, India \\ *Corresponding author: thejeshtn3@gmail.com
}

\begin{abstract}
The Ground water is a most valued universal wealth supporting the human well-being, along with ecosystem. It has become a significant and reliable cause of water supplies in both urban and rural areas under varying climatic conditions across the countries (Todd and Mays, 2005), due to its intrinsic qualities. Out of $37 \mathrm{M} \mathrm{km}^{3}$ of freshwater anticipated to be available on the earth, the ground water is about $22 \%$, which represents around 97\% of freshwater that is accessible for domestic use (Foster, 1998). In India, over $91 \%$ and $30 \%$ of population of rural, and urban respectively, depending on the ground water for the drinking and domestic purpose (1996, Reddy). The ground water is becoming critical economic tool in progressing Nations \& can supply to the poor people at lower rates more efficiently (IWMI, 2001).
\end{abstract}

Keywords: Digital elevation model, Land use, Land cover, Satellite imagery.

\section{Introduction}

Ground water is the major source of drinking water in both urban and rural India. Over the years, increasing population, urbanization and expansion in agriculture has led to the unscientific exploitation of this resource. It is an important source of water for the agricultural and the industrial sector. The demand for water has increased over the years and this has led to water scarcity in many parts of the world, especially in India. This alarming situation calls for a cost and time effective technique for proper evaluation of groundwater resources, management and planning. Interpreted remote sensing and GIS can provide the appropriate platform for convergent analysis of diverse data sets for decision making in ground water management and planning. The remote sensing technology and GIS tools have opened new paths in water resources studies.

Temporal data from remote sensing enables identification of groundwater aquifers and assessment of their changes, whereas, geographical information system (GIS) enables user-specific management and integration of multi-thematic data. Remote Sensing and GIS applications have been used by numerous scientists in mapping of groundwater potential zones
(Nampak. H et al., 2018; Sameen, M. I et.al 2018; Lv, F., \& Han, M (2018). and Ghayoumian, J, 2005). The Indian Remote Sensing programme is directed towards the realization of operational capabilities in space and ground segments of the technology for regular monitoring of earth resources and environment (Gupta and Roy, 2000). The spatio-temporal variations in rainfall and regional/ local differences in geology and geomorphology have led to an uneven distribution of ground water in different regions across the country.

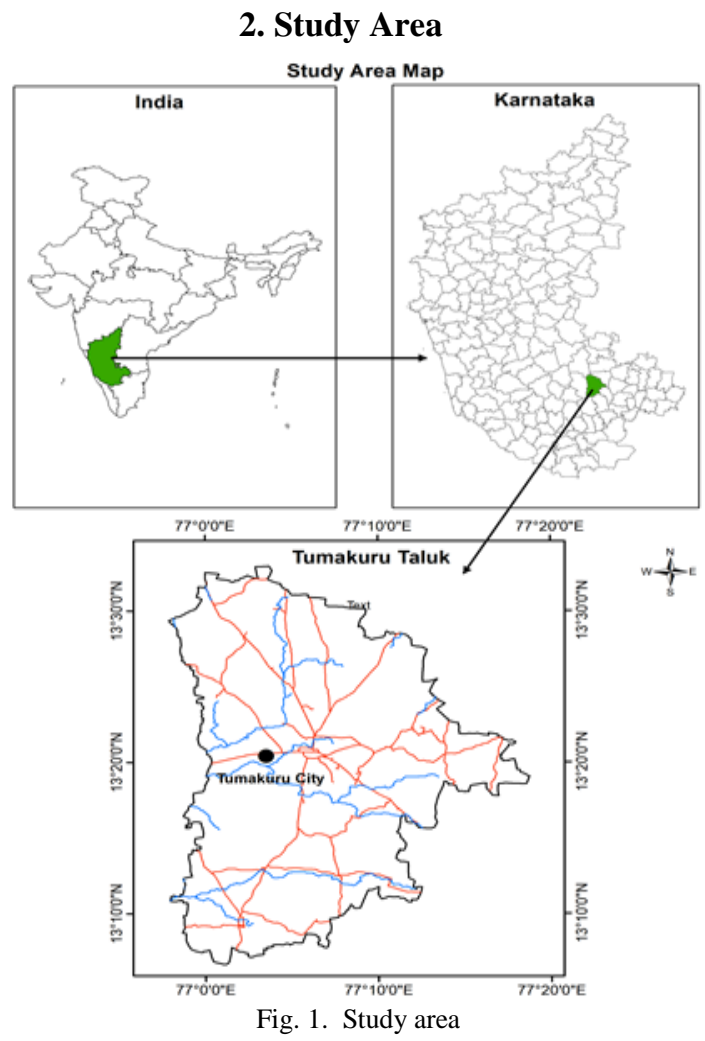

The Tumakuru district consisting of ten taluks and Tumakuru 
Taluk is selected in the present study. Tumakuru is one of the developing city in India, and is one of the fast developing urban areas of Karnataka. The schematic representation of study area is shown in, figure.

\section{A. Regional characteristics of study area}

In this study area, Tumakuru Taluk, falls under Tumakuru district of Karnataka State, India which is shown in Figure. Tumakuru is an industrial city situated on distance of $70 \mathrm{~km}$ northeast Bengaluru, capital of Karnataka. The Tumakuru taluk lies between $13.11^{\circ} \& 13.55^{\circ} \mathrm{N}$ Latitudes and $76.96^{\circ} \& 77.32^{\circ}$ E Longitudes. The altitude of study area ranges from 727 , to 1247 meters. The Average annual rainfall of this study area is 540.7 millimeter and yearly potential evapo-transpiration is around $1800 \mathrm{~mm}$, with monthly rates less than $100 \mathrm{~mm}$ during December and January months and over 250 millimeter during May month (Directorate of Economics \& Statistics, Karnataka). As the area is under semi-arid climatic condition the temperature start rising from January and reaches its peak value in May with a maximum temperature of around $40^{\circ} \mathrm{C}$.

\section{B. Population}

Tumakuru taluk had a population of 5.92 lakhs. The majority of economy of Tumakuru district's comes from agriculture and similarly Industries for Tumakuru city's.

\section{Geomorphology}

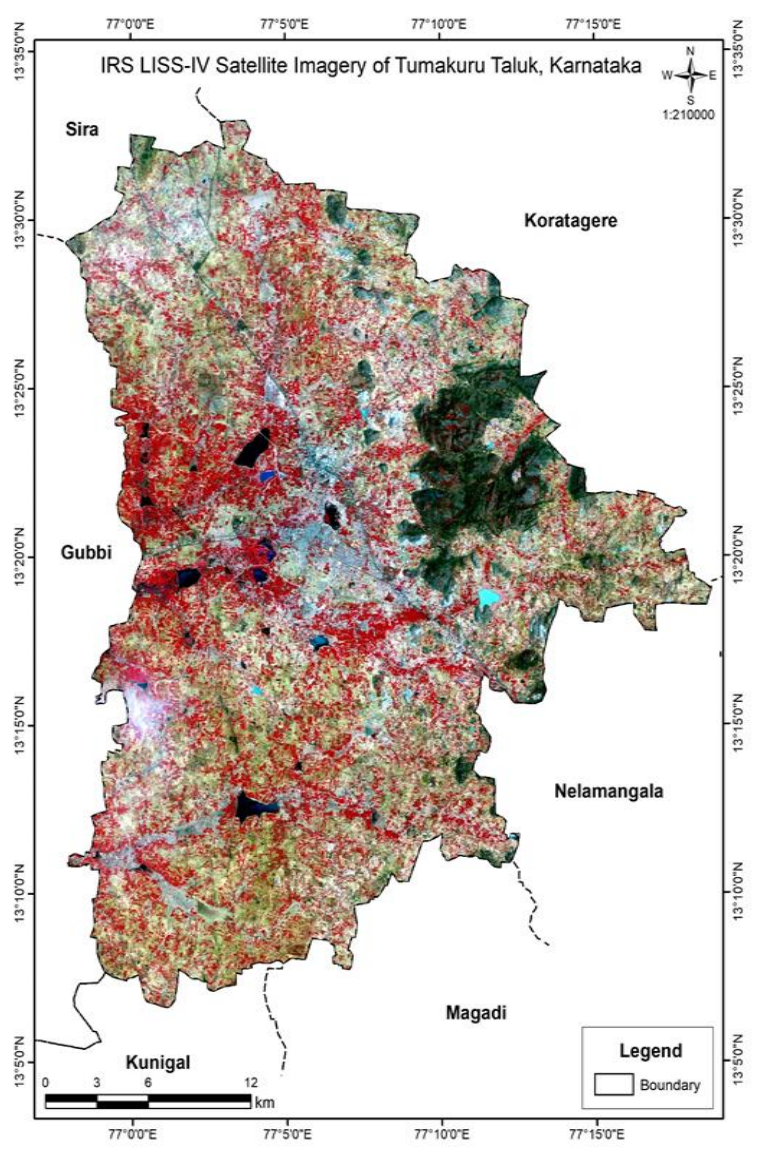

Fig. 2. Map showing study area extracted from Satellite image
The district is generally, open area excluding the south of Kunigal Taluk (covered with hills and dense forests). To the north of Devarayana Durga \& the east of Tumkur the region the hill ranges intersected by cultivated valleys that brings beautiful scenery. Western part of district is covered by wide range of hills.

In the eastern the area is covered by narrow range of granitic passing through the Taluks of Koratagere, and Madhugiri, and Pavagada \& northern parts of the Tumkur. This hills containing schistose rocks passes through Gubbi taluks, Sira, and Chikkanayakanahalli in the eastern part. The prominent hills in the eastern range of hills are Kamannda durga (1076m), Nidugal (1147m), Madhugiri durga (1198m), Channarayadurga $(1137 \mathrm{~m})$ Koratagiri $(878 \mathrm{~m})$, Devarayana durga (1186m), Nijagal (1085m), Hutri durga (1129) and Huliyar durga (843m) above mean sea level. The Landmass in this plains ranges between 450 to 840 metres above MSL. While, hilly areas range between 840 , to 1500 metres above mean sea level.

\section{Methodology}

The topo sheets used in the investigation area are skimmed, registered and mosaicked by means of ERDAS Imagine 9.1 Satellite information that is obtained was pre-processed and geo-corrected corresponding to registered topo sheets. Digitalization of forms from the Topo sheet were done and at the Digital Elevation Model (DEM) for the analysis zone was created

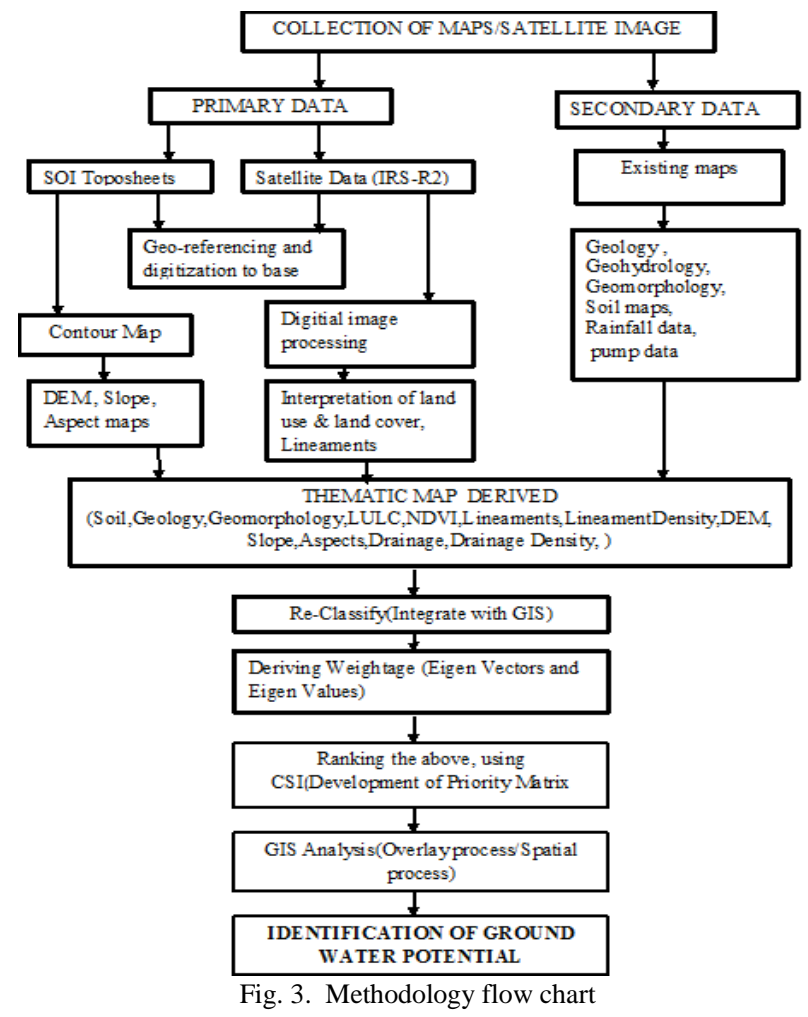




\section{Land Use and Land Cover}

Land use and land cover plays is an important role is considered for the "geo-hydrological studies because the land use pattern of any ground is a reflection of the complex physical processes" prevalent upon the earth's surface. These processes involves the impact of topography, geology and climatic conditions on the distribution of occurrence of water, vegetation and soils.

So it is significant for the future development and, management to have timely and, reliable information on environmental status through land use studies. The major landuse type in this investigation area is composed of settlements and built-up area. These land use classes are drafted from LISSIV satellite data and intense field verification which can be evidenced

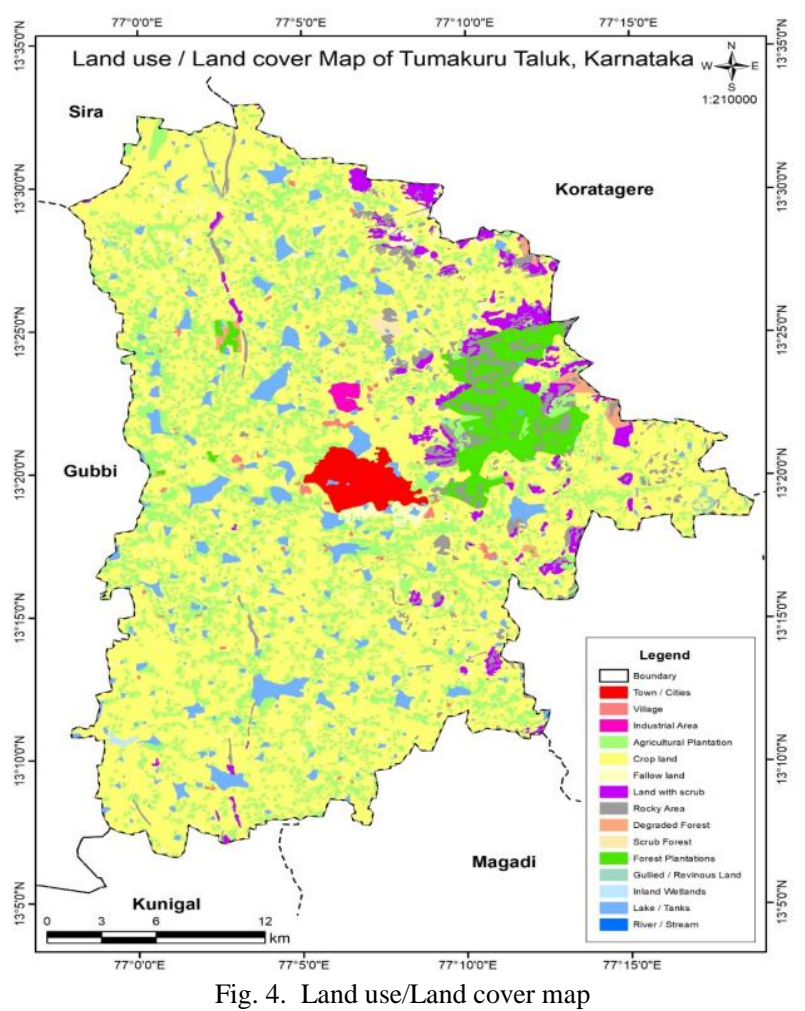

Fig. 4. Land use/Land cover map
Table 1

Aerial Extent of the Land use and Land cover

\begin{tabular}{|l|l|l|}
\hline & \multicolumn{1}{|c|}{$\begin{array}{c}\text { Area covered in } \\
\mathbf{K m}^{\mathbf{2}}\end{array}$} & $\begin{array}{c}\text { \% of area } \\
\text { covered }\end{array}$ \\
\hline Town / Cities & 16 & 1.6 \\
\hline Village & 5 & 0.4 \\
\hline Industrial Area & 2 & 0.2 \\
\hline Agricultural Plantation & 191 & 18.5 \\
\hline Crop Land & 634 & 61.6 \\
\hline Fallow Land & 15 & 1.5 \\
\hline Land with Scrub & 27 & 2.7 \\
\hline Rocky Area & 36 & 3.5 \\
\hline Degraded Forest & 5 & 0.5 \\
\hline Scrub Forest & 2 & 0.2 \\
\hline Forest Plantations & 37 & 3.6 \\
\hline Gullied / Revinous Land & 2 & 0.2 \\
\hline Inland Wetlands & 1 & 0.1 \\
\hline Lake / Tanks & 57 & 5.5 \\
\hline River / Stream & 0.1 & 0.01 \\
\hline Total & & 100 \\
\hline
\end{tabular}

\section{Conclusion}

- The land use and land cover mapping play a vital role in the development of agriculture, forest, urban development, rural development and other developmental activities.

- The land use and land cover pattern reveals the occurrence and identification of ground water zones.

- It gives the information about the crop acreage, production and estimation.

- It helps the identification of environmental protection zones.

- The highest land use pattern is crop land, it covers $61.6 \%$ of area $\left(634 \mathrm{~km}^{2}\right)$.

- The least land use pattern is river/streams, it covers $0.01 \%$ of area $\left(0.1 \mathrm{~km}^{2}\right)$.

- Based on the above land use and land cover patterns different types of agricultural crops and Horticultural plantation may be suggested.

\section{References}

[1] H. Nampak, B. Pradhan, H. MojaddadiRizeei, and H. J. Park, "Assessment of land cover and land use change impact on soil loss in a tropical catchment by using multitemporal SPOT-5 satellite images and revised universal soil loss equation model," in Land Degradation and Development, vol. 29, no. 10, pp. 3440-3455, 2018.

[2] M. I. Sameen, B. Pradhan, and S. Lee, "Self-learning random forests model for mapping groundwater yield in data-scarce areas," in Natural Resources Research, 2018.

[3] F. Lv, and M. Han, "Hyperspectral image classification based on improved rotation forest algorithm," in Sensors, vol. 18, no. 11, pp. 3601, 2018.

[4] J. Ghayoumian, B. Ghermezcheshme, S. Feiznia, and A. A. Noroozi, "Integrating GIS and DSS for identification of suitable areas for artificial recharge, case study Meimeh Basin, Isfahan, Iran," in Environmental Geology, vol. 47, no. 4, pp. 493-500, 2005. 